4. Malakhov V.A. (1996). Etyka. Kurs lektsiy: Navch. Posibnyk [Ethics. Lecture Course: Educational. textbook]. K. : Lybid (in Ukrainian).

5. Moskalets V.P. (1998). Rozvytok osobystosti uchnya metodom khudozhno-estetychnoyi ekzystentsial noyi hry [Student personality development by the method of artistic-aesthetic existential game]. Psykholoho-pedahohichni ta metodychni problemy rozvyvalnoho navchannya [Psychologicalpedagogical and methodological problems of developmental learning] [Za red. B. Skomorovskoho]. Ivano-Frankivsk (in Ukrainian).

Одержано статтю: 20.09.2019

Прийнято до друку: 18.10.2019

УДК $378.147: 746.1$

DOI: $10.15330 /$ esu. $17.310-317$

\author{
Валентина Мірошніченко, \\ доктор педагогічних наук, доцент, \\ Національна академія Державної Прикордонної \\ служби України імені Б. Хмельницького \\ (м. Хмельницький, Україна) \\ Valentyna Miroshnychenko, \\ Doctor of pedagogical sciences, Associate Professor, \\ National Academy of the State Border Guard Service \\ of Ukraine named after Bohdan Khmelnytskyi \\ (Khmelnytskyi, Ukraine) \\ mvi_2016@ukr.net \\ Олег Ставицький, \\ доктор педагогічних наук, доцент, \\ Національна академія Державної Прикордонної \\ служби України імені Б. Хмельницького \\ (м. Хмельницький, Україна) \\ Oleg Stavytskyi, \\ Doctor of pedagogical sciences, Associate Professor, \\ National Academy of the State Border Guard Service \\ of Ukraine named after Bohdan Khmelnytskyi \\ (Khmelnytskyi, Ukraine) \\ ostavik@ukr.net
}

\title{
ПЕДАГОГІЧНІ УМОВИ ФОРМУВАННЯ ГОТОВНОСТІ МАЙБУТНІХ ОФІЦЕРІВ ДО ВИКОРИСТАННЯ ЗТЕМ-ТЕХНОЛОГИЙ В ОСВІТНЬОМУ ПРОЩЕСІ ВИЩИХ ВІЙСЬКОВИХ НАВЧАЛЬНИХ ЗАКЛАДІВ
}

\section{PEDAGOGICAL CONDITIONS OF FORMING OF FUTURE OFFICERS' READINESS TO USAGE OF STEM-TECHNOLOGIES IN THE EDUCATIONAL PROCESS OF HIGHER MILITARY EDUCATIONAL ESTABLISHMENTS}

Стаття присвячена визначенню та обірунтуванню педагогічних умов формування готовності майбутніх офіцерів до використания STEM-технологій в освітньому прочесі.

Готовність майбутніх офічерів до використання STЕМ-технологій в освітньому прочесі авторами розумісться як інтегрована характеристика особистості, ио трунтується на усвідомленні курсантами ролі STEM-технологій як вагомого чинника набуття професійними компетентностяли на основі міждисииплінарних зв'язків, здатності до творчості та критичного професійного мисления.

На основі аналізу психолого-педагогічної літератури та з метою вдосконалення прочесу формувания готовності майбутніх офічерів до використания STЕМ-технологій в освітньому прочесі визначено такі педагогічні умови: формування професійної мотивачії майбутніх офіџерів за допомогою STEM-методик; запровадження спечкурсу “використання STEM-технологій у вищій військовій школі"; підготовка науково-педагогічних кадрів до 
застосувания stет-технологій в освітньому прочесі; методичне забезпечення використания stет-технологій в освітньому прочесі вищих військових навчальних закладів.

Ключові слова: формувания готовності, майбутні офічери, SТЕМ-технологій, освітній прочес, професійні компетентності, критичне мислення, педагогічні умови.

The article is devoted to defining and substantiation of pedagogical conditions of formation of future officers' readiness to use STEM technologies in the educational process.

The willingness of future officers to use STEM technologies in the educational process is understood by the authors as an integrated characteristic of the personality, based on the cadets' awareness of the role of STEM technologies as a significant factor in acquiring professional competences based on interdisciplinary connections and ability to work.

Attention is drawn to the conditionality of the content of future officers' training in the use of STEM technologies in the educational process as a set of theoretical knowledge, practical skills, different forms of training and interdisciplinary activities specific to their professional activity.

The educational process is reflected in a system of organizational, didactic and other measures aimed at implementing the content of higher education at a certain educational level in accordance with state educational standards.

In view of this, and given the importance of using STEM technologies in today's educational space, it is emphasized that only the traditional methods can achieve the desired result of the educational process. Therefore, it is advisable to formulate the readiness of future officers to use STEM technologies in the educational process.

The pedagogical conditions of this process are understood to mean circumstances, real situations that are deliberately created in the educational process, the task of which is to ensure its most efficient flow and achieve a specific goal, namely, to form the readiness of future officers to use STEM technologies.

On the basis of the analysis of the psychological and pedagogical literature and with the purpose of improving the process of forming the readiness of future officers to use STEM technologies in the educational process, the following pedagogical conditions have been determined:

formation of professional motivation of future officers with the help of STEM-methods; school";

introduction of a special course "the use of STEM technologies in a higher military

preparation of scientific and pedagogical staff for the application of stem technologies in the educational process;

methodological support for the implementation of the use of stem-technologies in the educational process of higher military educational establishments.

Key words: readiness formation, future officers, STEM technologies, educational process, professional competences, critical thinking, pedagogical conditions.

Постановка проблеми у загальному вигляді та ії зв'язок із важливими науковими чи практичними завданнями. Сучасні тенденції розвитку вищої освіти зорієнтовані на підготовку “фахівців завтрашнього дня", зміну ідеології освіти від "передавання готових знань" до формування універсальних знань і способів діяльності, фундаменталізацію та забезпечення цілісності професійної освіти, створення системи неперервної освіти і відкритого освітнього простору, що “забезпечують освіту через все життя" [1, с. 267].

Результати аналізу стану сформованості готовності майбутніх офіцерів до використання STEM-технологій в освітньому процесі засвідчують, що результати цього процесу не достатньо задовольняють вимоги, що пред'являє суспільство до сучасних фахівців. Тому актуальним $є$ питання щодо з'ясування особливостей цього 
процесу задля окреслення шляхів його удосконалення, визначення педагогічних умов його ефективного перебігу.

Аналіз останніх досліджень і публікацій, в яких започатковано розв'язання порушеної проблеми і на які спирається автор. Проблема використання новітніх технологій у підготовці фахівців у вищих військових навчальних закладах вивчалася І. Блощинським, Ю. Дем'янюком, О. Діденком, О. Торічним, І. Яремчуком та ін. Результати аналізу наукових праць із зазначеної проблеми дозволяють зробити висновок, що вчені розглядають використання новітніх педагогічних технологій як один із пріоритетних напрямів (видів) підготовки майбутніх фахівців. Осмислення окремих аспектів готовності майбутніх фахівців до використання різноманітних новітніх технологій здійснюється у низці робіт (О. Барни, О. Гермак, Р. Гуревича, T. Комар, С. Мохуна, А. Швеця, Д. Шулікіна, К. Яцко та ін.). Особливості STEMосвіти розглядають у своїх працях дослідники-педагоги О. Курносенко, А. Кух, О. Кух. Вони переконані, в необхідності використання саме цих технологій у підготовці майбутніх фахівців. Але у зазначених та інших наукових працях не знайшла достатнього відображення проблема використання stem-технологій у вишій військовій школі загалом, так і визначення та обгрунтування педагогічних умов формування готовності майбутніх офіцерів до використання STEM-технологій в освітньому процесі зокрема. Урахування зазначених наукових підходів спонукало нас до вибору тематики дослідження.

Формулювання цілей статті (постановка завдання). Метою статті $\epsilon$ визначення та обгрунтування педагогічних умов формування готовності майбутніх офіцерів до використання STEM-технологій в освітньому процесі.

Виокремлення невирішених раніше аспектів загальної проблеми, які суголосні із статтею. На думку І.Зязюна, педагогічна технологія - це сфера знання, яка включає методи, засоби навчання і теорію їх використання для досягнення цілей освіти [2].

Поняття “STEM" вживається для позначення популярного напряму в освіті, що охоплює природничі науки (Science), технології (Technology), технічну творчість (Engineering) та математику (Mathematics). Це напрям в освіті, при якому в навчальних програмах посилюється природничонауковий компонент + інноваційні технології. Технології використовують навіть у вивченні творчих, мистецьких дисциплін. У STEM-освіті навчання виступає не просто засобом передачі знань від учителя до учнів, воно є способом розширення свідомості і зміни реальності.

Досить активно використовують STEM-підхід в освітньому процесі зарубіжних країн, зокрема у Сполучених Штатах Америки. Програма STEM впроваджується там на державному рівні. Такий підхід запроваджено у багатьох провідних університетах США (Орегонський, Колорадський, університет штату Вашингтон, університет Маршала. До реалізації програми впровадження STEM в освіті також долучаються керівники провідних компаній в галузі IT-технологій і телекомунікацій. Серед меценатів $є$ представники таких відомих компаній, як $\underline{\text { Intel, } \underline{\text { Xerox }} \text {, Time }}$ Warner та інші. До проекту також залучені: фонд, заснований Біллом і Меліндою Гейтс та Нью-Йоркський фонд, заснований корпорацією Карнегі та ін. В результаті була створена некомерційна організація Change the Equation, що підтримує освіту за STЕМ-напрямками [3].

STEM-освіта передбачає формування критичного мислення та навичок дослідницької діяльності [4]. 
Виклад основного матеріалу дослідження 3 повним обгрунтуванням одержаних наукових результатів. Доречно згадати, що у STEM-освіті активно розвивається креативний напрямок, що включає творчі та художні дисципліни (промисловий дизайн, архітектура та індустріальна естетика i т.д.). Тому шо майбутнє, засноване виключно на науці, навряд чи когось порадує. Але майбутнє, яке втілює синтез науки і мистецтва, хвилює нас вже зараз. Саме тому вже сьогодні потрібно думати, як виховати кращих представників майбутнього. А на думку американських вчених, спроба активізувати освіту тільки в напрямку науки без паралельного розвитку Arts-дисциплін може призвести до того, що молоде покоління позбудеться навичок креативності. У штаті Массачусетс, наприклад, прийнято законодавство, яке зобов'язує проводити рейтинг шкіл не тільки за рівнем виконання учнями стандартних тестів, але також і по тому, наскільки навчальний план кожної школи сприяє посиленню креативності учнів. Так званий "індекс креативності" [5].

За результатами вивчення джерел встановлено, що STEM-підхід $\epsilon$ необхідною складовою для задоволення зростаючих потреб суспільства практично в усіх сферах. Наприклад, цей підхід застосовується в медицині, агропромисловому комплексі, енергетиці, робототехніці, IT, транспорті, промисловому та цивільному будівництві, тощо [3]. Отже, щоб переконатися у доцільності його використання та формування готовності майбутніх офіцерів до використання STEM-технологій в освітньому процесі звернемося до керівних документів, які регламентують зазначений процес у вищому військовому навчальному закладі. Зокрема, зосередимо увагу на прикладі Національної академії Державної прикордонної служби України імені Богдана Хмельницького (далі - НАДПСУ) як відомчого вищого військового навчального закладу прикордонного відомства України.

Так, Стратегією розвитку Національної академії Державної прикордонної служби України імені Богдана Хмельницького на період до 2021 року серед стратегічних цілей і завдань передбачено:

- удосконалення змісту освіти та програми підготовки офіцерів-прикордонників відповідно до вимог сьогодення, наукових досягнень, потреб відомства, суспільства та поглиблення наукової складової програм підготовки;

- удосконалення нормативного, наукового та навчально-методичного забезпечення навчального процесу, постійне поповнення внутрішніх сайтів НАДПСУ навчальними і науково-методичними матеріалами, забезпечення доступу до них усіх структурних підрозділів та кожного курсанта зокрема;

- удосконалення системи перепідготовки та підвищення кваліфікації фахівців відповідно до потреб прикордонного відомства;

- підвищення педагогічної майстерності науково-педагогічного складу, рівня наукової роботи та комп'ютерної грамотності;

- створення ефективної системи стажування науково-педагогічного складу; покращення якісного складу кадрового забезпечення навчального процесу;

- орієнтація інноваційної освітньої діяльності на підготовку фахівців, які володіють комплексними сучасними знаннями та можуть самостійно виконувати управлінські завдання з охорони державного кордону;

- упровадження технології інноваційного навчання, зокрема й сучасних інформаційно-телекомунікаційних технологій, спрямування їх на досягнення майбутніми випускниками компетентностей, адаптованих до вимог сьогодення [6, с. 14]. 
Також під час дослідження було враховано, що у відповідності до Положення про організацію освітнього процесу в Національній академії Державної прикордонної служби України імені Богдана Хмельницького освітній процес - це інтелектуальна, творча діяльність у сфері вищої освіти і науки, що провадиться в академії через систему науково-методичних і педагогічних заходів та спрямована на передачу, засвоєння, примноження і використання знань, умінь та інших компетентностей в осіб, які навчаються, а також на формування гармонійно розвиненої особистості [7, с. 6].

Мета освітнього процесу академії містить:

- активну участь під час формування та реалізації завдань державної та відомчої політики у сфері підготовки всіх категорій постійного, перемінного складу здатного за своїми теоретичним знаннями, практичними навичками ефективно діяти за призначенням, як в умовах освітнього процесу, так оперативнослужбової (оперативно-бойової) діяльності органів (оперативно-бойових підрозділів) охорони кордону;

- провадження на високому рівні освітньої діяльності, яка забезпечує здобуття всіма курсантами вищої освіти відповідного ступеня за обраними спеціальностями;

- наближення освітньої діяльності до нагальних потреб майбутньої професійної діяльності нарощування інтелектуального потенціалу відомства та держави [7, c. 9].

В академії освітній процес знаходить свій вияв у системі організаційних, дидактичних та інших заходів, спрямованих на реалізацію змісту вищої освіти на певному освітньому рівні відповідно до державних стандартів освіти. При цьому перелік навчальних дисциплін, що вивчаються майбутніми офіцерами, $\epsilon$ досить широким. Він містить такі блоки: загальнонаукові навчальні дисципліни, фахові навчальні дисципліни та блок військово-прикордонної складової. Військово-прикордонна складова становить приблизно половину годин навчального плану.

Тому особливої значимості набувають міждисциплінарні знання i міждисциплінарні зв'язки, уміння отримувати знання з одних дисциплін задля здатності їх практичного використання в тому числі на заняттях 3 інших дисциплін, під час стажування в підрозділах охорони кордону, уміння критично мислити, оперативно приймати професійні рішення.

Зважаючи на це та з урахуванням значимості використання STEM-технологій у сучасному освітньому просторі, на нашу думку, очевидно, що лише традиційними методами досягти бажаного результату такого процесу неможливо. Тому доцільним $\epsilon$ формування готовності майбутніх офіцерів до використання STEM-технологій в освітньому процесі.

За допомогою STEM-технологій майбутні офіцери мають змогу: аналізувати навчальну інформацію, творчо підходити до засвоєння навчального матеріалу й у такий спосіб зробити засвоєння знань доступнішим; формулювати власну думку, доводити власну позицію, аргументувати й дискутувати; навчитися слухати іншу людину, поважати альтернативну думку; моделювати різні ситуації професійної діяльності, збагачувати власний досвід через включення в різні професійні ситуації, їх моделювання; вчитися будувати конструктивні взаємини у групі, уникати конфліктів, розв'язувати їх, шукати компроміси, прагнути діалогу та консенсусу; розвивати навички проектної діяльності, самостійної роботи, виконання творчих робіт [8]. 
Як було 3'ясовано, значну роль відіграє готовність майбутніх офіцерів до використання STEM-технологій. Тому під час дослідження ми орієнтувалися на формування цієї готовності.

Було враховано, що вчені визначають готовність як вибіркову, прогнозовану активність особистості на етапі її підготовки до діяльності, така активність виникає як результат визначення професійної мети на основі усвідомлених потреб і мотивів [9].

Учені виділяють такі два підходи до визначення змісту поняття "готовність": функціональний та особистісний. Функціональний напрям розглядає готовність у зв'язку з психічними функціями, формування яких вважається необхідною умовою забезпечення результативності професійної діяльності. Функціональний підхід визначає готовність як особливий стан, що займає проміжне становище між психічними процесами та властивостями особистості. Відповідно до особистісного підходу психологічна готовність розглядається як зв'язок з особистісними передумовами до успішної діяльності [10, с. 37-38].

Нами було взято до уваги науковий підхід, згідно якого ефективність педагогічного процесу закономірно залежить від умов, в яких він відбувається. Науковець визначає педагогічні умови як чинники (обставини), від яких залежить ефективність функціонування педагогічної системи. Це обставина, при якій компоненти навчального процесу представлені в найкращій взаємодії, яка дає можливість вчителю плідно викладати, керувати навчальним процесом, а учням успішно вчитися [11, с. 34].

Готовність майбутніх офіцерів до використання STEM-технологій в освітньому процесі розуміємо як інтегровану характеристику особистості, що грунтується на усвідомленні курсантами ролі STEM-технологій як вагомого чинника набуття професійними компетентностями на основі міждисциплінарних зв'язків, здатності до творчості та критичного професійного мислення. Зміст підготовки майбутніх офіцерів до використання STEM-технологій в освітньому процесі обумовлено специфікою їх професійної діяльності. Він охоплює сукупність теоретичних знань, практичних умінь та навичок, різних форм занять та міждисциплінарних заходів.

Оскільки ж освітня практика може забезпечити досягнення цілей, тільки шляхом свідомого і цілеспрямованого створення і реалізації необхідних для цього педагогічних умов [12, с. 90], однією 3 найсуттєвіших проблем удосконалення підготовки майбутніх юристів в коледжах $\epsilon$ визначення, обгрунтування та реалізація педагогічних умов цього процесу.

Під педагогічними умовами цього процесу, 3 урахуванням думки С. Гаркавцева [12], розуміємо обставини, реальні ситуації, що свідомо створюються в освітньому процесі, завданням яких $€$ забезпечення найбільш ефективного його перебігу та досягнення конкретної мети, а саме - формування готовності майбутніх офіцерів до використання STEM-технологій.

На основі аналізу психолого-педагогічної літератури та 3 метою вдосконалення процесу формування готовності майбутніх офіцерів до використання stem-технологій в освітньому процесі визначено такі педагогічні умови:

- формування професійної мотивації майбутніх офіцерів за допомогою STEMметодик (створення освітнього середовища, наближеного до реальних умов професійної діяльності); 
- запровадження спецкурсу “використання STEM-технологій у вищій військовій школі" (обсяг - 56 год., 3 них 26 - аудиторні заняття, 30 - самостійна робота);

- підготовка науково-педагогічних кадрів до застосування stem-технологій в освітньому процесі (діяльність постійно діючого семінару 3 удосконалення готовності науково-педагогічних кадрів до використання сучасних педагогічних технологій, у тому числі STEM);

- методичне забезпечення використання stem-технологій в освітньому процесі вищих військових навчальних закладів (наявність спеціально обладнаних навчальних класів, сучасних комп'ютерних лабораторій, вільного доступу до наукових бібліотек через електронну мережу).

Висновки представленого у статті дослідження і перспективи подальших наукових розвідок із зазначеного напряму. Отже, ми виділяємо такі педагогічні умови, що забезпечують ефективність формування готовності майбутніх офіцерів до використання STEM-технологій в освітньому процесі: формування професійної мотивації майбутніх офіцерів за допомогою STEM-методик; запровадження спецкурсу “використання STEM-технологій у вищій військовій школі"; підготовка науково-педагогічних кадрів до застосування stem-технологій в освітньому процесі; методичне забезпечення реалізації застосування stem-технологій в освітньому процесі вищих військових навчальних закладів.

Визначення та обгрунтування педагогічних умов дає змогу конкретизувати сутність і специфіку формування готовності майбутніх офіцерів до використання STEM-технологій. Цей напрямок $€$ перспективним напрямком подальших наукових пошуків з проблеми. Також перспективним $є$ детальне обгрунтування та реалізація кожної із визначених педагогічних умов

\section{Література}

1. Білецька Г.А. Природничо-наукова підготовка майбутніх екологів у вищих навчальних закладах : монографія. Хмельницький : ХНУ, 2014. 378 с.

2. Технологізація освіти в контексті удосконалення професійного розвитку особистості. Розвиток педагогічної і психологічної наук в Україні 1992-2002 pp. : зб. наук. праць до 10-ти річчя АПН України. Ч. 2. Харків : “ОВС”, 2002. С. 28-44.

3. STEM у світі. https://uk.wikipedia.org/wiki/STEM.

4. Курносенко O. B STEM-освіта: проблеми та напрямки впровадження. URL: http : // tsiurupynskschool 2. edukit. kherson. Ua / distancijne _ navchannya / mo_vchiteliv_fizikomatematichnih_nauk/stem-osvita problemi ta napryamki vprovadzhennya.

5. STEM-освіта. URL: https://imzo.gov.ua/stem-osvita/.

6. Стратегія розвитку Національної академії Державної прикордонної служби України імені Богдана Хмельницького. Хмельницький, 2015. 54 с.

7. Положення про організацію освітнього процесу в Національній академії Державної прикордонної служби України імені Богдана Хмельницького : наказ ректора НАДПСУ від 30.11.2015 № 221. Хмельницький : Видавництво НАДПСУ, 2016. $85 \mathrm{c}$.

8. Огляд інтерактивних методів. URL: http://multycourse.com.ua/ua/page/19/69

9. Дьяченко М. И., Кандыбович Л. А. Психологические проблемы готовности к деятельности. Мн.: Изд-во БГУ, 1976. $176 \mathrm{c}$.

10. Малинівська Л.І., Васильєва Р.Ю.,Семенець Л.М. Психолого-педагогічні аспекти формування готовності до професійної діяльності фахівців 3 охорони праці та цивільного захисту. Науковий журнал "Інноваційна педагогіка"№ 4. 2018. С. 36-38.

11. Бабанский Ю. К. Оптимизация учебно-воспитательного процесса : методологические основы. М. : Просвещение, 1982. 192 с.

12. Гаркавцев Є. І. Педагогічні умови формування професійної надійності майбутніх працівників органів внутрішніх справ України : дис. ... канд. пед. наук : 13.00.04. Харків, 2015. 292 с 


\section{References}

1. Biletska H. A. Pryrodnycho-naukova pidhotovka maibutnikh ekolohiv u vyshchykh navchalnykh zakladakh : monohrafiia. Khmelnytskyi [Natural science training of future ecologists in higher education institutions]: KhNU, 2014. $378 \mathrm{~s}$. [in Ukrainian]

2. Tekhnolohizatsiia osvity $\mathrm{v}$ konteksti udoskonalennia profesiinoho rozvytku osobystosti. Rozvytok pedahohichnoi i psykholohichnoi nauk v Ukraini 1992-2002 rr. [Technology education in the context of improving the professional development of the individual. Development of pedagogical and psychological sciences in Ukraine 1992-2002]: zb. nauk. prats do 10-ty richchia APN Ukrainy. Ch. 2. Kharkiv: "OVS", 2002. S. 28-44. 09.11.2019 [in Ukrainian]

3. STEM u sviti. [ STEM in the world] https://uk. wikipedia.org/wiki/STEM. 09.11.2019 [in Ukrainian]

4. Kurnosenko O. V STEM-osvita: problemy ta napriamky vprovadzhennia [STEM education: problems and directions of implementation]. URL: http : // tsiurupynsk-school 2. edukit. kherson. Ua / distancijne navchannya / mo_vchiteliv_fiziko-matematichnih_nauk/stem-osvita problemi ta napryamki vprovadzhennya.16.10.2019 [in Ukrainian]

5. STEM-osvita.[STEM education] URL: https://imzo.gov.ua/stem-osvita/ 12.11.2019 [in Ukrainian]

6. Stratehiia rozvytku Natsionalnoi akademii Derzhavnoi prykordonnoi sluzhby Ukrainy imeni Bohdana Khmelnytskoho [Development Strategy of the National Academy of the State Border Guard Service of Ukraine named after Bogdan Khmelnitsky]. Khmelnytskyi, 2015. 54 s. [in Ukrainian]

7. Polozhennia pro orhanizatsiiu osvitnoho protsesu v Natsionalnii akademii Derzhavnoi prykordonnoi sluzhby Ukrainy imeni Bohdana Khmelnytskoho [Regulations on the Organization of the Educational Process at the Bogdan Khmelnytsky National Academy of State Border Guard Service of Ukraine]: nakaz rektora NADPSU vid 30.11.2015 № 221. Khmelnytskyi : Vydavnytstvo NADPSU, 2016. 85 s. [in Ukrainian]

8. Ohliad interaktyvnykh metodiv [An overview of interactive methods]. URL: http : // multycourse. com. ua/ua/page/19/69 08.12.2019 [in Ukrainian].

9. Diachenko M. Y., Kandyibovych L. A. Psykholohycheskye problemyi hotovnosty k deiatelnosty. [Psychological problems of readiness for activity] Mn.: Yzd-vo BHU, 1976. 176 s. [in Russian]

10. Malynivska L.I., Vasylieva R.Iu.,Semenets L.M. Psykholoho-pedahohichni aspekty formuvannia hotovnosti do profesiinoidiialnosti fakhivtsiv z okhorony pratsi ta tsyvilnoho zakhystu [Psychological and pedagogical aspects of the formality of readiness before professional careers for the protection of civilians and civilians]. Naukovyi zhurnal "Innovatsiina pedahohika"№ 4. 2018. S. 36-38. [in Ukrainian]

11. Babanskyi Yu. (1982) Optymyzatsyia uchebno-vospytatelnoho protsessa: metodolohycheskye osnovyi [Optimization of educational process] M. : Prosveshchenye, 1982. $192 \mathrm{~s}$. [in Russian]

12. Harkavtsev Ye. I. (2015) Pedahohichni umovy formuvannia profesiinoi nadiinosti maibutnikh pratsivnykiv orhaniv vnutrishnikh sprav Ukrainy [Pedagogical mindfulness of the professional requirements of the mayor organizations of the internal help of Ukraine] : dys. ... kand. ped. nauk : 13.00.04. Kharkiv, 2015. $292 \mathrm{~s}$. [in Ukrainian] 